Adam Fijałkowski

ORCID: 0000-0002-1049-875X

Uniwersytet Warszawski Wydział Pedagogiczny

\title{
Między teorią a praktyką wychowania - czego dziś możemy nauczyć się z Orbis sensualium pictus Jana Amosa Komeńskiego
}

\author{
Between theory and practice of education \\ - what we can learn today from \\ Orbis sensualium pictus by John Amos Comenius
}

DOI: $10.34739 /$ szk.2021.08.02

\begin{abstract}
Streszczenie: Za najważniejsze zasługi Komeńskiego w historii wychowania i myśli pedagogicznej uważa się jego uzasadnienie i zastosowanie poglądowości w nauczaniu, opisanie i uzasadnienie systemu klasowo-lekcyjnego z podziałem na przedmioty nauczania, a także przypisuje mu się zasługi w dziele „naprawy spraw ludzkich” na świecie w duchu „wartości humanistycznych". Uważna lektura podręczników Komeńskiego, w tym w szczególności Orbis sensualium pictus (1658), ukazuje, że wszystkie te „zasługi” są wynikiem uproszczonej lub wręcz błędnej interpretacji jego dzieł, w tym w szczególności - skupieniu się jedynie na teoretycznych i wizjonerskich tekstach Komeńskiego i nieuwzględnienia jego podręczników. Słowa kluczowe: Komeński, podręczniki, poglądowość, system klasowo-lekcyjny, wartości humanistyczne
\end{abstract}

\begin{abstract}
The most important merits of Comenius in the history of education are his justification and the use of visualization in teaching, describing and justifying the class-lesson system with a breakdown into subjects of teaching, and he is credited with the work of the "improvement of human affairs" in the world in the spirit of "humanistic values". A careful reading of Comenius' textbooks, in particular his Orbis sensualium pictus (1658), shows that all these "merits" are the result of a simplified interpretation or even misinterpretation of his works, in particular - focusing only on the theoretical and visionary texts by Comenius and not taking into account his textbooks.
\end{abstract}

Keywords: Comenius, schoolbooks, visualization, class-lesson system, humanistic values

W 1658 roku w norymberskiej oficynie wydawniczej Michaela Endtera ukazała się niewielka ilustrowana książeczka Jana Amosa Komeńskiego (Jan Amos Komenský lub Comenius, 1592-1670) pod tytułem Orbis sensualium pictus. Hoc est Omnium fundamentalium in Mundo Rerum \& in Vita Actionum 
Pictura et Nomenclatura (Komeński, 1658). Było to pierwsze z bardzo wielu wydań tej książki, którą uważa się za pierwowzór obecnych podręczników. Znalazła w nim zastosowanie między innymi zasada poglądowości w nauczaniu (Okoń, 1998: 175-178). Podręcznik ten szybko zyskał uznanie. Już w roku opublikowania jego pierwszego wydania w Norymberdze znalazł się w „Magdeburskim porządku szkolnym" (Comenius, 1996: 40) jako podręcznik zalecany do nauczania. Jego sukces był ogromny: ponad 200 wydań w ciągu niemal 200 lat, tłumaczenia na ponad 20 języków (Pilz, 1967: 54-61). Najwięcej wydań, bo 197, zawierało tekst łaciński. Było 167 wydań z tłumaczeniem niemieckim, $50 \mathrm{z}$ francuskim, $39 \mathrm{z}$ węgierskim, $37 \mathrm{z}$ polskim, $28 \mathrm{z}$ czeskim, $15 \mathrm{z}$ rosyjskim, $14 \mathrm{z}$ angielskim i innymi. Dane podawane przez Kurta Pilza sprzed ponad pół wieku nie są jednak precyzyjne. Według obecnych ustaleń wydań było więcej. Najstarsze wydania w poszczególnych językach, jako książki szkolne, ukazały się: po łacinie i niemiecku (1658), angielsku (1659), francusku (1666), włosku (1666), polsku (1667), węgiersku (1669), duńsku (1672), szwedzku (1682), czesku (1685), rosyjsku (1768), starogrecku (1802); a jako obiekty badań naukowych po raz pierwszy: po serbsko-chorwacku (1913), bułgarsku (1957), japońsku (1988), holendersku (1991), hiszpańsku (1993), koreańsku (1999), rumuńsku (2016) oraz katalońsku (2017). Niewiele innych książek szkolnych w dziejach wychowania doczekało się takiej liczby wydań i tłumaczeń (Bieńkowski, 1977: 38). Orbis pictus stanowił więc przez dwa stulecia dobrą odpowiedź na rzeczywiste zapotrzebowanie społeczne. Cenili go zarówno wielcy tamtych czasów, jak i - co może jest w kontekście oddziaływania społecznego ważniejsze - setki tysięcy pedagogów, nauczycieli, rodziców i dzieci, zwykłych ludzi (Bečkova, 1991; Bieńkowski, 1975: 85-100). Już choćby z tego powodu podręcznik ten należy do najważniejszych źródeł w historii wychowania.

Mimo to podręczniki Komeńskiego nie znalazły się w wydawanej z inicjatywy Bogdana Suchodolskiego serii wydawniczej „Biblioteka klasyków pedagogiki. Pisarze obcy”, w której opublikowano przeważnie pisma teoretyczne Komeńskiego: Wielkq dydaktykę (1956), przeważnie mniejsze teksty teoretyczne lub regulaminy szkolne zebrane w tomie Pisma wybrane (1964) oraz Pampaedię (1973) - wszystkie w tłumaczeniu Krystyny Remerowej (1898-1986) z wstępami i odpowiadającemu stanowi badań sprzed wielu lat opracowaniu Bogdana Suchodolskiego. Mimo że Bogdan Suchodolski już w 1964 roku zauważył potrzebę wydania w „Bibliotece klasyków pedagogiki” zarówno Janua linguarum reserata, jak i Orbis sensualium pictus (Suchodolski, 1964: VI), to jednak nigdy do tego nie doszło. Jeśli Bogdana Suchodolskiego uznajemy obecnie za komeniologa (Sztobryn, 2020: 24), zadajemy sobie pytanie, dlaczego nie wydał dwóch najważniejszych podręczników Komeń- 
skiego, które zarówno w jego epoce, jak i aż do początków XIX wieku były wznawiane jako podręczniki szkolne, które, dodajmy, przyniosły autorowi największą sławę i bez których pewnie podzieliłby los setek sobie współczesnych autorów, których pisma teoretyczne, obecnie - rękopisy lub stare druki - czytane są wyłącznie przez nieliczne grono specjalistów w specjalistycznych bibliotekach.

Podręcznik Orbis sensualium pictus (1658) Jana Amosa Komeńskiego jest uwieńczeniem trwających ponad trzydzieści lat zmagań i doświadczeń dydaktycznych autora. Za jego najważniejszą zasługę uważamy zgodnie zastosowanie w tym podręczniku w praktyce zasady poglądowości, którą sformułował Komeński po 1627 roku w Wielkiej dydaktyce (1956: 199). Wszystko zaczęło się „w upalne letnie dni” (per dies caniculares) 1627 roku, gdy Komeński czytał w zamku Vlčice na Podgórzu Karkonoskim „niedaleko źródeł Łaby" (prope Albis fontes) książki z biblioteki Adama Zilvára (łac. Silverus) (Komeński 1657: 3; Bieńkowski 2000: 75). Tam do jego rąk trafiła m.in. Didactica Eliasa Bodinusa, opublikowana równo 400 lat temu (Bodinus 1621; Toischer, 1899), co, jak Komeński sam pisał, spowodowało początek jego trwałego zainteresowania dydaktyką, czyli sztuką nauczania. Od 1627 roku, będąc pod bezpośrednim wpływem tej lektury, Komeński rozpoczął prace nad swoją dydaktyką. Jego pierwsza wersja zatytułowana Didactica to jest Umění umělého vyučování powstała w języku czeskim (1627-1632), a następnie, za radą przyjaciół, autor przełożył ją na łacinę (1632-1638) i nazwał Didactica magna (Wielka dydaktyka) (Kumpera, 1992: 229-230). Bodinus opublikował swoją dydaktykę pod tytułem Bericht von der Natur und vernünfftmessigen Didactica oder Lehrkunst. Książeczka ta powstała jako forma obrony w czasie konfliktu z nauczycielami szkół humanistycznych w Hamburgu. Konflikt ten zakończył się nie tylko atakiem słownym, ale wręcz pobiciem na ulicy i wypędzeniem Bodinusa z Hamburga latem 1621 roku. 0 co spierano i bito się na ulicach „na grucie dydaktycznym” w Hamburgu 400 lat temu? Podstawowym założeniem Bodinusa było to, podobnie jak wcześniej Wolfganga Ratkego (1571-1635), że sztuka nauczania musi odwoływać się do natury. Nauczanie początkowe powinno, według Bodinusa, koncentrować się na poznaniu przez uczniów rzeczy, a nie od razu treści abstrakcyjnych. W odróżnieniu od Ratkego i jego uczniów, Bodinus uważał jednak, że nauczyciel winien w przekazywaniu wiedzy oddziaływać na pięć zmysłów uczniów, a przede wszystkim na słuch i wzrok. W nauczaniu poglądowym powinno się, według niego, posługiwać wyraźnym i zrozumiałym dla dzieci drukowanym podręcznikiem z ilustracjami. Trzeba podkreślić, że Bodinus zalecał stosowanie ilustracji, zwłaszcza w nauczaniu początkowym, ponieważ uważał on, że czynią one nauczanie bardziej efektywnym i ciekawszym zarówno dla ucznia, 
jak i nauczyciela (Bodinus, 1621: 2-4). Bodinus był przekonany, podobnie jak wcześniej Ratke, że nauczanie należy rozpocząć od języka ojczystego. Przywiązywał jednak większą wagę niż Ratke do metodyki nauczania początkowego. Twierdził, że systematyczne sylabizowanie w nauczaniu czytania typu: $b a, b e, b i, b o, b u, c a, c e, c i, c o, c u$ itd. - stosowane w praktyce szkolnej co najmniej od czasów Kwintyliana (Kwintylian 1995: 111), jest żmudne i pochłania zbyt dużo czasu. Postulował zatem, by od nauczania kształtu liter przechodzić od razu do czytania słów w języku ojczystym. Nauczanie czytania powinno przebiegać równolegle z nauczaniem pisania: najpierw całego alfabetu, a następnie - od razu całych słów, bez systematycznego sylabizowania. Bodinus propagował więc syntetyczną metodę nauczania, lecz bez żmudnego sylabizowania (zgłoskowania). Postulował jednocześnie, aby nauczanie czytania łączyć z nauczaniem pisania, co odbiegało od przyjętej od starożytności praktyki. Proponował również przejście do nauczania gramatyki na podstawie podręcznika Donata. Z tekstu wynika, że mogło tu chodzić nie tyle o Ars minor Aeliusza Donata z IV wieku, ile o jakąś późniejszą przeróbkę lub adaptację, w której słowo Donat nie oznaczało imienia, lecz tytuł. Bodinus zamierzał przyspieszyć nauczanie gramatyki łacińskiej dzięki równoległemu nauczaniu łaciny i języka ojczystego (paralelizm), w czym jego postulaty zbliżały się do wcześniejszych zaleceń Ratkego. Nauczanie powinno być - zdaniem Bodinusa - łączone z doświadczeniami z życia codziennego uczniów, co musi wpłynąć w oczywisty sposób na program nauczania. Mniej będzie w nim dziejów i literatury starożytnej, więcej informacji odnoszących się do współczesnej im rzeczywistości (Bodinus, 1621: 5-98). Na końcu dziełka wspomina Bodin o potrzebie nauczania dziewcząt, ale nie poświęca temu zagadnieniu więcej uwagi (Bodinus, 1621: 99).

Komeński z Dydaktyki Bodinusa mógł zaczerpnąć bardzo wiele: przede wszystkim uznanie ważnej roli polisensorycznej poglądowości - w tym w szczególności ilustracji - w nauczaniu oraz w rozumieniu dydaktyki jako „Sztuki nauczania”, która musi wynikać z natury, uzasadnienie używania języka ojczystego, zalecenie unikania stosowania kar fizycznych, potrzebę uproszczenia i skrócenia nauczania języków obcych w szkołach humanistycznych, nauczanie realiów. Jak zauważył Bodinus, realizacja tych postulatów miała się przyczynić do zwiększenia dostępności szkół i dostosowania ich do ówczesnych potrzeb społeczno-gospodarczych. W ten sposób szkoły miały się stawać bardziej egalitarne, a wykształcenie powinno przestać być traktowane jako jeden z wyznaczników statusu społecznego. Wywołało to bardzo ostry sprzeciw ze strony zwolenników klasycznej, ośmio-, dziewięciolub dziesięcioletniej szkoły humanistycznej, której program i metody nauczania zapewniały elitom wykształcenie będące jednym $\mathrm{z}$ wyznaczników ich 
statusu społecznego. Egalitaryzm szkół musiał się podobać Komeńskiemu i pewnie wywarł wpływ na sformułowanie przez niego egalitarnej koncepcji dydaktyki jako sztuki „nauczania wszystkich wszystkiego” (Okoń 1956: 21) między innymi w Wielkiej dydaktyce. Nie bez znaczenia była tu także ideologia społeczna braci czeskich, której Komeński był gorącym zwolennikiem (Fijałkowski, 2012: 60-67).

Dla zrozumienia genezy Orbis pictus konieczna jest w tym miejscu uwaga, że w postulatach dydaktycznych Bodinusa bardzo istotne miejsce zajmowała rola poglądowości polisensorycznej, ilustratywnej i czynnej w procesie nauczania, która obecna jest także w poglądach Komeńskiego. To najwyraźniej pod wpływem Bodinusa Komeński w Wielkiej dydaktyce pisał: „Niech to będzie złotą zasadą dla uczących, ażeby, co tylko mogą, udostępniali zmysłom, a więc: rzeczy widzialne wzrokowi, słyszalne słuchowi, zapachy węchowi, rzeczy smak mające smakowi, namacalne dotykowi, a jeżeli coś jest uchwytne dla kilku zmysłów, należy je kilku zmysłom naraz udostępnić" (Komeński, 1956: 199). Pozornie proste zastosowanie ilustracji w celu przyspieszenia nauczania budziło jednak poważne kontrowersje. Bodinusa oskarżono o sprzyjanie edukacyjnej łatwiźnie. Trudność opublikowania ilustrowanego podręcznika dla dzieci wynikała więc nie tylko z niedoskonałości technik drukarskich, bo te w XVII wieku były już dobrze rozwinięte, ani z wysokich kosztów wydania, bo te, dzięki zastosowaniu tańszych technik ilustratorstwa książkowego - drzeworyt zamiast miedziorytu - można było zredukować, ani z niedostrzegania możliwej roli ilustracji w nauczaniu, bo stosowano je co najmniej od średniowiecza, lecz ze stosunku dydaktyków do ilustracji jako możliwego narzędzia mnemotechniki, tzw. pamięci lokalnej, czyli nauczania bez zrozumienia. Aby powstał ilustrowany podręcznik Orbis sensualium pictus, Komeński potrzebował trzydziestu lat namysłu, własnej praktyki nauczycielskiej w Przerowie, Fulneku, Lesznie, Elblągu i Sárospataku, lektur autorów „ruchu dydaktycznego” z Wolfgangiem Ratkem na czele, wsparcia przyjaciół z kręgu Samuela Hartliba (ok. 1600-1662), pewnie spod znaku różokrzyża (Cegielski, 1994: 80, 90-92, 115, 125-127), a wreszcie pomocy poetów (Fruchtbringende Gesellschaft) i drukarzy (Enderowie) w Norymberdze, gdzie opublikował swoje dzieło (Fijałkowski, 2012: 60-113, 176-222; Fijałkowski, 2015: 5-32). Oskarżenie o stosowanie ilustracji jako formy mnemotechniki nie było bynajmniej bezpodstawne, ponieważ nawiązuje do zainteresowań młodego Komeńskiego i jego nauczyciela z Herborn (1611-1613), Jana Henryka Alsteda (1588-1638), mnemotechniką i kabalistyką chrześcijańską, m.in. Rajmunda Lulla (ok. 1232-1315) (Yates, 1977: 372-374; Schmidt-Biggemann 1983: 138-154 et al.; Schmidt-Biggemann, 2013). Stąd tak częste w dydaktyce Komeńskiego podkreślanie znaczenia 
zrozumienia (np. Komeński, 1956: 123-124, 128), a nie tylko zapamiętania materiału nauczania (Strasser, 2000).

Kolejną rzeczą, którą dziś możemy nauczyć się z Orbis sensualium pictus, jest krytyczny stosunek do przyjętej ogólnie w dydaktyce opinii, że „model systemu klasowo-lekcyjnego z podziałem na przedmioty, który dziś „z przyzwyczajenia” jest realizowany w szkole, opracował wielki czeski pedagog, Jan Amos Komeński” (Klus-Stańska, 2018: 19). Opinie takie powtarzają także obecnie historycy wychowania (Massalski, Bożyk, 2020: 57), mimo że już Łukasz Kurdybacha wykazał, że podział na klasy wprowadzono dwieście lat przed Komeńskim, w połowie XV wieku, w szkołach Braci Wspólnego Życia w północnej Nadrenii i w Niderlandach. Dodajmy, że nie jest to bez znaczenia dla pedagogiki humanistycznej, ponieważ w szkole takiej uczył się między innymi młody Erazm z Rotterdamu. System klasowy przejęli następnie sto lat przed Komeńskim m.in. jezuici oraz Jan Sturm we wzorcowym luterańskim gimnazjum humanistycznym w Strasburgu w 1538 roku (Kurdybacha, 1967: 310-312). Zwróciłem też uwagę, że o Komeńskim jako rzekomym twórcy systemu klasowo-lekcyjnego, przed II wojną światową nie pisał Bogdan Nawroczyński w Zasadach nauczania (wydanie 1 w 1930 roku i następne - tu wydanie: 1987). Co więcej - Stanisław Kot słusznie zauważał, że „uczniowie w jednym i tym samym czasie jednym tylko zajmować się powinni przedmiotem, że zmienianie treści lektury lub ćwiczeń z każdą godziną, może tylko chaos w głowach młodzieży wywołać" (Kot, 1934: 315), co jest zresztą nawiązaniem wprost do zasady 4 z XVI rozdziału Wielkiej dydaktyki (Komeński, 1956: 126-127), a także zaprzeczeniem systemu klasowolekcyjnego z podziałem na przedmioty. Ten sam autor zauważył również słusznie, że „nie każde dziecko dojrzałe jest do pobierania nauki według zakreślonego planu; Komeński sam to rozumiał, pozostawiając szkole swobodę rozkładu materiału na lata, miesiące i dni (Kot, 1934: 307). Ponieważ w pedagogice walczy się o „uwolnienie szkoły od systemu klasowo-lekcyjnego" (Śliwerski, Paluch, 2021), warto zastanowić się, czy przy okazji nie „uwolnimy" szkoły od Komeńskiego.

Powstaje jednak pytanie: czy Komeński rzeczywiście jest twórcą systemu klasowo-lekcyjnego z podziałem na przedmioty? Dorota Klus-Stańska słusznie zauważyła (2018: 66-68), że do powojennej dydaktyki, którą wpisuje ona w paradygmaty obiektywistyczne i nazywa dydaktyką normatywną, bardzo wiele przekonań wniósł pedagog radziecki Iwan Kairow (1893-1978), którego dwutomowy podręcznik pt. Pedagogika opublikowano w Warszawie, w 1950 roku (było to tłumaczenie wydania moskiewskiego z 1948 roku). Ta sama autorka zauważa także, że podstawowe zasady nauczania - uczenia się w polskiej powojennej dydaktyce normatywnej zaczerpnięto właśnie z peda- 
gogiki Kairowa (Klus-Stańska 2018: 68). Dotyczy to także interpretacji Komeńskiego. Kairow pisał, że „klasowo-lekcyjny system nauczania jest to taka organizacja pracy szkolnej, przy której uczniowie zgrupowani są w poszczególnych klasach stosownie do wieku i poziomu przygotowania, a nauczanie każdego przedmiotu odbywa się za pomocą szeregu lekcji, zgodnie z ustalonym rozkładem. Klasowo-lekcyjny system nauczania jest jednym z najcenniejszych osiągnięć w dziedzinie pedagogiki. Pierwszym, który go jasno opisał i uzasadnił, był Jan Amos Komensky" (Kairow, 1950: 141). Radziecki uczony nie podał źródła swej hipotezy, którą najwyraźniej przyjęto następnie jako pewnik. Kairow, jak można przypuszczać, nie znał podręczników Komeńskiego, ponieważ w Rosji wydawane były one w XVIII wieku, w czasach Katarzyny II (Fijałkowski, 2008: 43), lub na początku XIX wieku (Sankt Petersburg 1817). Mógł znać natomiast przekład rosyjski Wielkiej dydaktyki (Moskwa 1893). Możemy domyślać się, że Kairow, pisząc o Komeńskim jako twórcy systemu klasowo-lekcyjnego, odwoływał się przede wszystkim do zasady 7 rozdziału XVI Wielkiej dydaktyki, w którym czytamy między innymi, że „a) Całokształt nauk ma być dokładnie podzielony na klasy tak, aby wcześniejsze nauki późniejszym wszędzie torowały światło. b) Czas ma być starannie podzielony tak, aby na każdy rok, każdy miesiąc, każdy dzień i każdą godzinę przypadała jakaś specjalnie odmierzona praca. c) Tego podziału czasu i pracy ma się ściśle przestrzegać, aby niczego nie pominąć, niczego nie poprzestawiać" (Komeński, 1956: 132). Zwróciliśmy jednak wyżej uwagę na to, że w tym samym rozdziale, w zasadzie 4, Komeński pisał również, jak słusznie zauważył Kot, żeby uczyć w danym czasie jednego tylko przedmiotu (Komeński, 1956: 126-127). Cytowaną zasadę 7 możemy interpretować na przykład jako uzasadnienie nauczania zintegrowanego, w którym również należy zachować porządek, by nie popaść w chaos. Komeński pisał wprawdzie w rozdziale XXIX Wielkiej dydaktyki m.in. o idei podręczników dla każdej klasy szkoły elementarnej: dla klasy pierwszej Violarium (grządka fiołków), dla drugiej - Rosarium (ogród róż), dla trzeciej - Viridarium (trawnik zielony) itd. (Komeński, 1956: 292-293), ale nigdy takich podręczników w praktyce nie napisał. Zarówno Janua linguarum reserata (1631), jak i ilustrowany Orbis sensualium pictus (1658) nie są podręcznikami dla danej „klasy”, dla danego wieku i poziomu uczniów ani nie są podręcznikami do nauczania poszczególnych przedmiotów.

To, że Orbis sensualium pictus nie jest podręcznikiem dla konkretnej klasy, można zobaczyć choćby na przykładzie „żywego alfabetu” (Komeński, 2015: 60-61). Może on służyć zarówno do nauczania czytania (dzięki zastosowaniu metody fonetycznej), a więc do nauczania początkowego, do nauczania wiedzy „o świecie” w szkole języka ojczystego (od 6 do 12 roku życia), 
jak i do nauczania łaciny, którą Komeński zalecał nauczać od 12 roku życia (chodzi tu o zdania łacińskie: cornix cornicatur, agnus balat, cicada stridet itd., które, jak wykazałem, wpisują się w sięgającą Warrona (116-27 p.n.e.) i Swetoniusza (70-150 n.e.), a żywą i w średniowieczu, i w XVI-XVII wieku, szkolną tradycję voces variae animantium) (Fijałkowski, 2007; Fijałkowski, 2008: 46-48; Fijałkowski, 2012: 281-336). Dotyczy to zresztą całego podręcznika. Komeński we „Wprowadzeniu do Czytelnika” Orbis sensualium pictus wyraźnie pisał, że najpierw uczniowie nauczą się z „żywego alfabetu” kształtów liter, następnie będą oglądać i przerysowywać obrazki, w dalszej kolejności - czytać w języku ojczystym same tytuły, następnie także czytanki w języku ojczystym, porównując wyrazy z rzeczami na ilustracjach i w swoim otoczeniu (poglądowość), a na końcu - czytać także w języku obcym i porównywać tekst obcy, drukowany w równoległej kolumnie, z tekstem w języku ojczystym (Komeński, 2015: 53-55). Można więc stosować ten podręcznik, według zaleceń Komeńskiego, od początku szkoły języka ojczystego do początku szkoły języka łacińskiego, a więc od 6 do 12-13 roku życia. Jest to więc rodzaj podręcznika permanentnego, do którego się wraca na różnych etapach życia, ale z którego się także „wyrasta”, żeby czytać „pilnie inne dobre księgi” i być uczonym, mądrym i pobożnym (Komeński, 2015: 365).

Podobnie Orbis sensualium pictus nie jest podręcznikiem do jakiegoś określonego przedmiotu. Jest w nim zawarta wiedza zarówno z teologii, jak i kosmografii, mineralogii, botaniki, zoologii, medycyny, ogrodnictwa, rolnictwa, rzemiosł, nauk społecznych, prawnych, politycznych. Jest to rodzaj encyklopedii, pomysł na danie wszystkim ludziom wiedzy ogólnej, zintegrowanej, ściśle uporządkowanej, praktycznej, pansofii (Sztobryn, 2020). Zresztą sam Komeński nadał mu początkowo roboczy tytuł „encyklopedyjka rzeczy dostępnych zmysłom" (Encyclopaediola sensualium) (Fijałkowski, 2008: 36; Komeński, 2015: 27). Podręcznik zbudowany jest tak, że z poprzedniej lekcji wynika kolejna, według ściśle określonego porządku - jak w cytowanej wyżej zasadzie 7 rozdziału XVI Wielkiej dydaktyki.

Tak więc z podręcznika Orbis sensualium pictus możemy się dowiedzieć również, że Komeński nie był w praktyce zwolennikiem systemu klasowolekcyjnego z podziałem na przedmioty ani go nie uzasadniał - przynajmniej według rozumienia Iwana Kairowa.

Z podręcznika tego możemy dowiedzieć się też, jak pojmował wiedzę Komeński i jaki był jego stosunek do prądów intelektualnych epoki. Po pierwsze, świat według Komeńskiego był wyraźnie teologiczny: rozdział pierwszy zatytułowany jest „Bóg”, a ostatni, 150 (od liczby psalmów?): „Sąd Ostateczny". Świat wychodzi więc od Boga-Stwórcy i do Boga-Sędziego wraca (Fijałkowski, 2008: 53-56). Cała pansofia Komeńskiego jest w gruncie rzeczy 
„chrestosofią”. Nic więc dziwnego, że Komeński i Kartezjusz nie mogli znaleźć wspólnego języka podczas spotkania (Sztobryn, 2020: 27-29). W rozdziale III Orbis sensualium pictus pt. „Niebo” Komeński pisze: „Niebo obraca się i okrąża Ziemię, stojącą w środku" (Komeński, 2015: 67). Ilustracja poglądowo ugruntowuje geocentryczną wizję budowy świata - mimo że Komeński w 1614 roku nabył w Heidelbergu rękopis Kopernika De revolutionibus (Fijałkowski, 2008: 49-52), mimo że było to już po śmierci Galileusza, Kartezjusza i Keplera.

Innym paradoksem jest, że Komeński, który w swoim życiu doświadczył tyle zła wyrządzonego jemu i jego najbliższym przez wojnę, poświęca wojnie aż pięć rozdziałów w Orbis sensualium pictus (rozdz. 139-143), nigdy jej nie krytykując. Co więcej - kończy rozdział 143 o oblężeniu miasta beznamiętnym zdaniem: „Miasto siłą zdobyte będzie splądrowane, zburzone, niekiedy z ziemią zrównane” (Komeński, 2015: 347). I pisał tak człowiek, który stracił Magdalenę, pierwszą żonę, oraz dwoje dzieci podczas spalenia Fulneku przez wojska hiszpańskie w służbie cesarza (1622), który musiał nocą uciekać przed Polakami z palącego się Leszna (1656). Podobnie beznamiętnie opisane są okrutne „Kaźnie złoczyńców” (rozdz. 125 Orbis sensualium pictus): „Złodzieje na szubienicy są wieszani przez kata; cudzołożnicy ścinani; mordercy i rozbójnicy (piraci) albo dla połamania kości na kole są rozkładani, albo na pal nabici; czarownice na stosie są palone. Niektórym przed wykonaniem kaźni wyrywają język, albo na pieńku rękę odrąbują, albo żelazem przypalają. Tych, którym życie darowano, przywiązuje się do pręgierza, wybija się stawy, sadza na osła, obcina uszy, chłoszcze rózgami, znaczy piętnem, wypędza, skazuje na galery albo na wieczne więzienie. Zdrajców ojczyzny ćwiartuje się" (Komeński, 2015: 310-311). I to wszystko jest w podręczniku dla dzieci. Inny świat, inni ludzie, inne doświadczenia życiowe, inna wrażliwość...

Zupełnie inny jak w Wielkiej dydaktyce jest w Orbis sensualium pictus również obraz praktyki szkolnej (rozdz. 97): „Szkoła jest warsztatem, w którym umysły młode do cnoty są formowane i podzielona jest na klasy. Nauczyciel zasiada na katedrze, uczniowie na ławkach. On naucza, oni uczą się. Niektóre rzeczy są im pisane kredą na tablicy. Część uczniów siedzi przy stole i pisze, on poprawia błędy. Inni stoją i recytują zadane na pamięć. Niektórzy rozmawiają, zachowują się swawolnie i niedbale; ci są karani kijem i rózgą" (Komeński, 2015: 255). W tekście czytanki w Orbis sensualium pictus nauczyciel pracuje więc tylko z jednym uczniem w klasie, co Bogdan Nawroczyński nazywał „indywidualizującym nauczaniem” (Nawroczyński, 1987: 213) rodem ze starożytności i średniowiecza. Nie ma pracy z grupą uczniów, z których najwyraźniej tylko część uczy się pisania, a część - wyłącznie czytania. Jest to nie tylko zaprzeczenie systemu klasowo-lekcyjnego, ale więcej - jest to nauczanie pamięciowe, czyli najwyraźniej bez zrozumienia, a więc jest to 
zaprzeczenie zasady: „rzecz - pamięć - język - ręka” z zasady 5 XVI rozdziału Wielkiej dydaktyki (Komeński, 1956: 128). Jako rzecz normalną w praktyce szkolnej ukazuje Komeński stosowanie kar fizycznych dla nudzących się i nic dziwnego! - uczniów. To z kolei zaprzeczenie między innymi łacińskiego motta na jego winiecie autorskiej, stosowanej na kartach tytułowych dzieł wydawanych od 1648 roku aż do końca XVIII wieku: Omnia sponte fluant, absit violentia rebus („wszystko niech płynie swobodnie, niech nie będzie przemocy rzeczom") (Fijałkowski, 2021: 223-227). Tekst łaciński czytanki, w odróżnieniu od ilustracji, jest dziełem Komeńskiego. Najwyraźniej są to więc dla niego rzeczy całkowicie normalne w życiu codziennym szkoły.

Podobne zastrzeżenia budzić może przekazywana $\mathrm{w}$ podręczniku szkolnym wiedza o ptaku rajskim, jednorożcu, smoku i bazyliszku jako realnych zwierzętach, a także o słoniu jako zwierzęciu li tylko pociągowym (Komeński, 2015: 103, 117, 121, 115). W XIX wieku niektórzy pedagogowie byli również zgorszeni ukazaniem na ilustracjach ludzi bez ubrania: rozdz. 35: „Człowiek”, rozdz. 37: „Członki człowieka zewnętrzne”, rozdz. 74: „Łaźnia” oraz rozdz. 87: „Pływanie” (Komeński, 2015: 130, 134, 208, 234). Jednak nie wiemy, czy Komeński miał wpływ na powstanie tych ilustracji - on był w Lesznie lub w Amsterdamie, a podręcznik drukowano w Norymberdze. Można te ilustracje traktować jako element niemieckiej kultury mieszczańskiej w połowie XVII wieku, bo z pewnością nie sympatyzujących z kalwinizmem braci czeskich w tym czasie, oraz innego jak w XIX wieku i często także obecnie stosunku do nagości w sferze publicznej.

Podsumowując możemy stwierdzić, że uważna lektura Orbis sensualium pictus weryfikuje wiele przyjętych w literaturze przedmiotu tez na temat poglądowości, na temat Komeńskiego jako rzekomego „twórcy” systemu klasowo-lekcyjnego, stosunku do nauki tamtego czasu, a także na temat praktyki życia codziennego i praktyki wychowawczej. Burzy ona wiele naszych wyobrażeń, które budujemy jedynie na podstawie dzieł teoretycznych Komeńskiego. Na zadane na początku tekstu pytanie o przyczyny niewydania najważniejszych podręczników Komeńskiego przez Bogdana Suchodolskiego w „Bibliotece klasyków pedagogiki” możemy odpowiedzieć z dużą dozą prawdopodobieństwa, że Suchodolskiemu taki obraz twórczości Komeńskiego zdecydowanie nie odpowiadał. Podręczniki Komeńskiego na pewno nie były „postępowe”. Z punktu widzenia powojennej pedagogiki Suchodolskiego podręczniki Komeńskiego były najwyraźniej anachroniczne lub wręcz „wsteczne”. Wolał zdecydowanie te teksty Komeńskiego, które służyły mu do ukazania go jako pedagoga „postępowego”, głosiciela „wartości humanistycznych” i „naprawy świata”, a nie Komeńskiego - realistę, który dostosowuje swoje teksty do ówczesnych gustów odbiorców podręczników szkolnych. 
Klasycznym przykładem może być książka Bogdana Suchodolskiego pt. Labirynty tożsamości (1972), w której autor odwołuje się do wczesnego dzieła Komeńskiego pt. Labirynt świata i raj serca z 1623 roku (Komeński, 1914; Kumpera, 1992: 256-257), aby tłumaczyć - oczywiście według swojego rozumienia - „labirynty świata” w latach sześćdziesiątych i siedemdziesiątych XX wieku i bronić „wartości humanistycznych” wobec zagrożeń cywilizacji naukowo-technicznej i enigmatycznie, w duchu marksistowskim opisanej, kontestacji społeczno-kulturowej na Zachodzie w '68 roku.

Wydaje się więc, że lektura wyłącznie traktatów teoretycznych Komeńskiego zdecydowanie nie wystarcza. Podręczniki, choćby z powodów „marketingowych”, czyli - musiały „się sprzedać”, bardziej dostosowane były do realiów świata, w którym żyli ich potencjalni czytelnicy. Pamiętamy, że, zgodnie z zasadą poglądowości, uczniowie mieli porównywać świat w podręczniku ze światem, w którym żyli. Podręczniki Komeńskiego, w tym Orbis sensualium pictus, są więc ważnym uzupełnieniem wiedzy z często wizjonerskich i momentami trudnych do interpretacji traktatów teoretycznych Komeńskiego. Bez odniesienia „podręcznikarskiego” często możemy błądzić i dokonywać nadinterpretacji pism Komeńskiego. Prawda o Komeńskim leży - jak wykazałby pewnie Arystoteles - pośrodku: jest Komeński wizjoner, humanista, dydaktyk i, niestety, ograniczony wyznaniowo uczony, ale jest też Komeński realista, który dostosowywał się do realiów społecznych czasów, w których żył. Myślę, że pisząc o Komeńskim, nie powinniśmy zapominać o obu tych perspektywach: wizjonerskiej i społecznej.

\section{Bibliografia}

Bečkova Marta, Bieńkowski Tadeusz, Čapkova Dagmar, Znajmość dzieł Jana Amosa Komeńskiego na ziemiach czeskich, słowackich i polskich od połowy XVII w. do czasów obecnych, Warszawa 1991.

Bieńkowski Tadeusz, Znajomość i recepcja podręczników Komeńskiego w szkołach w Polsce w wieku XVII i XVIII, w: Jan Amos Komenský a Polsko. Referáty přednesené na čs.-polském semináři uspořádaném k 30. výroči vzniku Polské lidové republiky ve dnech 29.-30. listopadu 1974 v Praze, Praha 1975.

Bieńkowski Tadeusz, Komeńskiego metody $i$ środki przekazywania wiedzy w szkole, w: Komeński a współczesność. Materiały z Polsko-Czechosłowackiej Konferencji Komeniologicznej zorganizowanej z okazji XXX-lecia Czechosłowackiej Republiki Socjalistycznej, red. T. Bieńkowski, Wrocław 1977.

Bieńkowski Tadeusz, Jan Amos Komeński o nauczaniu i wychowaniu, Pułtusk 2000.

Bodinus Elias, Bericht von der Natur und vernünfftmessigen Didactica, oder LehrKunst: Nebensthellen und Sonnenklaren Beweiß, wie heutiges Tages der studierenden Jugend die rechten fundamenta verruckt entzogen werden... Omnia faciliora facit Ratio, Ordo et Modus, [s. l.], [Hamburg?] 1621. 
Cegielski Tadeusz, „Ordo ex Chao”. Oświecenie różokrzyżowców i początki masonerii spekulatywnej 1614-1738, Warszawa 1994.

Comenius und unsere Zeit. Geschichtliches, Bedenkenswertes und Bibliographisches, hrsg. von R. Golz, W. Korthaase, E. Schäfer, Baltsmannweiler 1996.

DJAK 1- Dílo Jana Amose Komenského = Johannos Amos Comenii Opera omnia, ed. A. Škarka et al., Praha 1969.

Fijałkowski Adam, A Latin Text of the „vocal alphabet“ in the Orbis sensualium pictus of J.A. Comenius, „Studia Comeniana et Historica” nr 37, Uhersky Brod 2007, s. 164-179.

Fijałkowski Adam, Orbis pictus - Świat malowany Jana Amosa Komeńskiego / Orbis pictus - die Welt in Bildern des Johann Amos Comenius, Warszawa 2008.

Fijałkowski Adam, Tradycja i nowatorstwo w Orbis sensualium pictus Jana Amosa Komeńskiego, Warszawa 2012.

Fijałkowski Adam, Wstęp do: Jan Amos Komeński, Świat w obrazach rzeczy dostępnych zmysłom = Orbis sensualium pictus [łac.-niem.-pol.], wstęp i przekład A. Fijałkowski, Warszawa 2015.

Kairow Iwan (red.), Pedagogika, t. 1-2, Warszawa 1950.

Klus-Stańska Dorota, Paradygmaty dydaktyki. Myśleć teoriq o praktyce, Warszawa 2018.

Komeński Jan Amos, Opera didactica omnia, cz. 1, Amsterdam 1657.

Komeński Jan Amos, Labirynt świata i raj serca, przekł. J. Pindór, Cieszyn 1914.

Komeński Jan Amos, Wielka dydaktyka, przekł. K. Remerowa, wstęp i oprac. B. Suchodolski, Wrocław 1956.

Komeński Jan Amos, Pisma wybrane, przekł. K. Remerowa, wstęp i oprac. B. Suchodolski, Wrocław 1964.

Komeński Jan Amos, Pampaedia, przekł. K. Remerowa, wstęp i oprac. B. Suchodolski, Wrocław 1973.

Komeński Jan Amos, Świat $w$ obrazach rzeczy dostępnych zmysłom = Orbis sensualium pictus [łac.-niem.-pol.], wstęp i przekład A. Fijałkowski, Warszawa 2015.

Kot Stanisław, Historia wychowania, t. 1, Lwów 1934.

Kumpera Jan, Jan Amos Komenský. Poutník na rozhraní věků, Ostrava 1992.

Kurdybacha Łukasz (red.), Historia wychowania, t. I, Warszawa 1967.

Kwintylian Marek Fabiusz, Kształcenie mówcy I, 1, 30, przekł. M. Brożek, w: Źródła do dziejów wychowania i myśli pedagogicznej, oprac. S. Wołoszyn, t. I, Kielce 1995.

Massalski Adam, Bożyk Izabela, Historia wychowania i myśli pedagogicznej. Skrypt dla studentów, Warszawa 2020.

Nawroczyński Bogdan, Zasady nauczania, w: tenże, Dzieła wybrane, wybór, przedmowa i wstęp A. Mońka-Stanikowa, t. II, Warszawa 1987.

Okoń Wincenty, Zasady dydaktyki, Warszawa 1956.

Okoń Wincenty, Wprowadzenie do dydaktyki ogólnej, Warszawa 1998.

Pilz Kurt, Johann Amos Comenius. Die Ausgaben des Orbis Sensualium Pictus, Nürnberg 1967.

Schmidt-Biggemann Wilhelm, Topica universalis. Eine Modellgeschichte humanistischer und barocker Wissenschaft, Hamburg 1983.

Schmidt-Biggemann Wilhelm, Geschichte der christlichen Kabbala, t. 2: 1600-1660, Stuttgart-Bad Cannstatt 2013.

Strasser Gerhard F., Emblematik und Mnemonik der frühen Neuzeit im Zusammenspiel: Johannes Buno und Johann Justus Winckelmann, Wiesbaden 2000. 
Suchodolski Bogdan, Wstęp do: Komeński Jan Amos, Pisma wybrane, przekł. K. Remerowa, wstęp i oprac. B. Suchodolski, Wrocław 1964.

Sztobryn Sławomir, W poszukiwaniu pansofii Komeńskiego w badaniach polskich komeniologów, B. Sitarska (red.), Pansofia Jana Amosa Komeńskiego w interpretacjach i reinterpretacjach polskich i europejskich komeniologów, „Siedleckie Zeszyty Komeniologiczne, seria pedagogika“, t. VII, Siedlce 2020, s. 23-36.

Śliwerski Bogusław, Paluch Michał, Uwolnić szkołę od systemu klasowo-lekcyjnego, Kraków 2021.

Toischer Wandelin, Die Didaktik des Elias Bodinus, „Mitteilungen der Gesellschaft für deutsche Erziehungs- und Schulgeschichte“, R. 9, 1899, s. 209-228.

Yates Frances A., Sztuka pamięci, przekł. W. Radwański, posłowie L. Szczucki, Warszawa 1977. 